\title{
ANALISIS PERILAKU MASYARAKAT KOTA PONTIANAK DALAM MENGHADAPI PANDEMI VIRUS CORONA (COVID-19)
}

\author{
STEVEN \\ Stvndavid07@gmail.com \\ Sekolah Tinggi Ilmu Ekonomi Indonesia Pontianak
}

\begin{abstract}
At the beginning of 2020, the whole country was struck by the Corona virus pandemic (Covid-19) which caused panic in all countries where hundreds of thousands of people were infected and thousands more died. For Indonesia Corona virus itself (Covid-19) has been determined as a national disaster that must be completely eradicated, for that the central government has appealed to each local government to provide guidance to the community in overcoming this outbreak so that it can run effectively and efficient.One of them is the regional government in Pontianak, where Pontianak is the highest number of Corona (Covid19) positive patients in West Kalimantan, with 78 positive patients infected with Corona (Covid-19) compared to other regions in West Kalimantan. Therefore this study aims to analyze the behavior of Pontianak city people in dealing with the Corona virus pandemic (Covid-19). Samples taken were 382 people in Pontianak City. The results of this study indicate that the behavior displayed by people who do not comply with government regulations is based on the perception of the Pontianak city community itself. The research method used by this research is literature study with a quantitative descriptive approach.
\end{abstract}

\section{Keywords: Covid-19 Pandemic, Behavior, Pontianak City}

\begin{abstract}
ABSTRAK
Di awal tahun 2020, seluruh negeri dilanda pandemi virus Corona (Covid-19) yang menimbulkan kepanikan di seluruh negara di mana ratusan ribu orang tertular dan ribuan lainnya meninggal dunia. Untuk virus Corona Indonesia sendiri (Covid-19) sudah ditetapkan sebagai bencana nasional yang harus diberantas tuntas, untuk itu pemerintah pusat mengimbau kepada setiap pemerintah daerah agar memberikan pembinaan kepada masyarakat dalam menanggulangi wabah ini agar dapat berjalan efektif. dan efisien. Salah satunya adalah pemerintah daerah di Pontianak, dimana Pontianak merupakan jumlah penderita positif Corona (Covid-19) tertinggi di Kalimantan Barat, dengan 78 penderita positif terjangkit Corona (Covid-19) dibandingkan dengan daerah lain di Barat. Kalimantan Oleh karena itu penelitian ini bertujuan untuk menganalisis perilaku masyarakat kota Pontianak dalam menghadapi pandemi virus Corona (Covid-19). Sampel yang diambil sebanyak 382 orang di Kota Pontianak. Hasil penelitian ini menunjukkan bahwa perilaku yang
\end{abstract}


ditampilkan oleh masyarakat yang tidak mematuhi peraturan pemerintah didasarkan pada persepsi masyarakat kota Pontianak itu sendiri. Metode penelitian yang digunakan dalam penelitian ini adalah studi literatur dengan pendekatan deskriptif kuantitatif.

Kata Kunci: Pandemi Covid-19, Perilaku, Kota Pontianak

\section{PENDAHULUAN}

Pada awal tahun 2020 ini dunia dikejutkan dengan adanya wabah virus corona (Covid-19) yang menginfeksi hampir seluruh negara di dunia, yang dimana virus ini pertama kali muncul dan ditemukan di Provinsi Wuhan Cina. Semenjak Januari 2020 WHO telah menyatakan bahwa dunia masuk kedalam darurat global terkait virus ini yang menjadi fenomena luar biasa yang terjadi di bumi pada abad ke-21. Hal ini dapat dilihat dari banyaknya event-event besar (pertandingan-pertandingan olahraga internasional contohnya) yang batal dan ditunda akibat adanya pandemi virus corona (Covid-19) ini. Terhitung pada Bulan Mei 2020 ini sebanyak 5.401.612 yang terinfeksi virus corona (Covid-19), meninggal sebanyak 343.804, dan yang sembuh sebanyak 2.247.151 hampir di seluruh negara di dunia.

Untuk negara Indonesia sendiri pemerintah juga sudah menetapkan bencana nasional untuk virus corona (Covid-19) ini terhitung mulai tanggal 29 Februari 2020 hingga 29 Mei 2020 terkait pandemi ini dengan jumlah waktu 91 hari. Salah satu langkah pemerintah utuk mengatasi virus corona (Covid-19) ini adalah dengan menerapkan Social Distancing. Konsep ini menjelaskan bahwa untuk dapat mengurangi bahkan memutus mata rantai infeksi Covid-19, seseorang harus menjaga jarak aman dengan manusia lainnya minimal 2 meter, tidak melakukan kontak langsung dengan orang lain dan menghindari pertemuan massal.

Provinsi Kalimantan Barat khususnya Kota Pontianak yang merupakan daerah terbanyak kasus positif corona (Covid-19) dibandingkan daerah-daerah lainnya di Kalimantan Barat tentu saja menjadi perhatian pemerintah daerah itu sendiri. 
Pandemi

Covid-19,

Perilaku, Kota

Pontianak

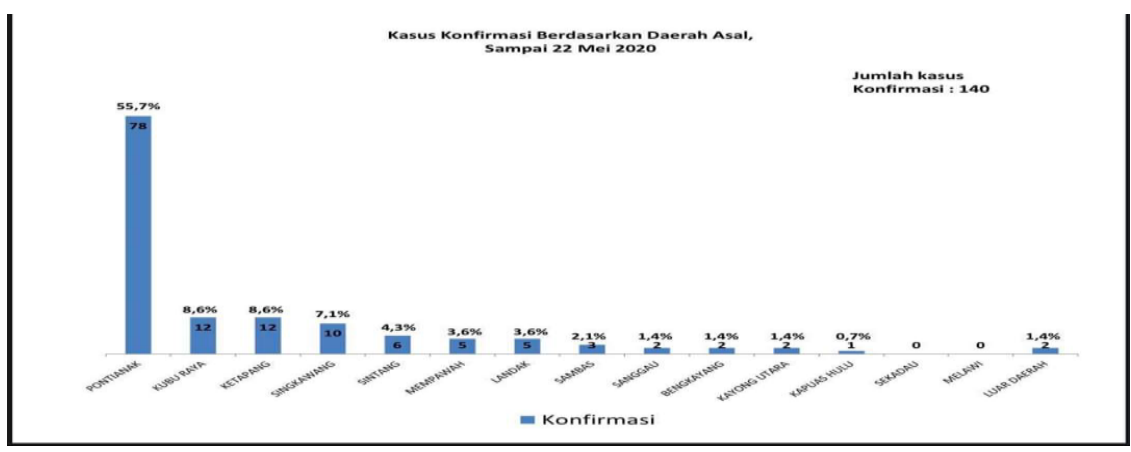

Gambar 1

Kasus Konfirmasi Covid-19 di Kalimantan Barat

Sumber : Dinas Kesehatan Provinsi Kalimantan Barat

Pada gambar 1 diatas dapat dilihat bahwa di Kota Pontianak yang terkonfirmasi virus Covid-19 adalah sebanyak 78 kasus lebih banyak dibandingkan dengan daerah lainnya di Kalimantan Barat yang dimana terlihat bahwa daerah Sekadau dan Melawi masih nihil kasus sampai saat ini. Hal ini tentu saja menjadi perhatian bagi pemerintah Kota Pontianak dalam mencegah atau mengatasi virus Covid-19 ini.

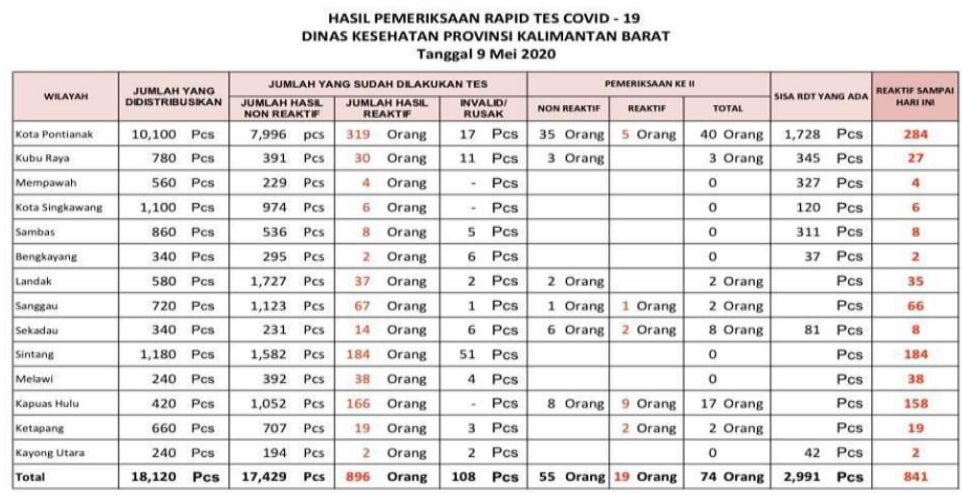

Gambar 2

Hasil Pemeriksaan Rapid Test Provinsi Kalimantan Barat Sumber : Dinas Kesehatan Provinsi Kalimantan Barat

Pada gambar 2 diatas dapat terlihat bahwa Kota Pontianak menjadi daerah yang memiliki jumlah reaktif terbesar dan berpotensi positif Covid-19 sebanyak 284 orang dibandingkan dengan daerah-daerah lainnya. Hal ini tentu saja menjadi perhatian yang serius bagi pemeritah untuk mencegah lebih banyak penularan lagi dari virus Covid-19 ini. 
Pada dasarnya perilaku masyarakat yang tidak menyikapi himbauan pemerintah dengan baik, seperti contohnya pemerintah sudah meliburkan para siswa dan mahasiswa untuk tidak berkuliah dan bersekolah ataupun memberlakukan bekerja didalam rumah, namun kondisi ini malahan dimanfaatkan oleh banyak masyarakat untuk berlibur atau pulag kampung. Selain itu walaupun Indonesia sudah diberlakukan bencana nasional untuk Covid-19 ini ternyata masih banyak masyarakat yang memilih berbelanja di pasar-pasar yang menyebabkan terjadinya kerumunan massa secara tidak langsung. Begitu juga di Kota Pontianak masih banyak masyarakat yang tidak mengikuti anjuran pemerintah untuk sekedar dirumah saja dan benar-benar keluar kalau ada kepentingan yang mendesak saja.

Perilaku masyarakat khususnya di Kota Pontianak yang seakan-akan tidak peduli dengan himbauan dari pemerintah tentu saja akan menjadi bumerang dan menyebabkan penyebaran virus Covid-19 yang lebih besar lagi di Kota Pontianak dan bahkan di daerah-daerah lainnya yang ada di Kalimantan Barat. Perilaku yang tidak norma ini memicu peneliti untuk menganalisa lebih jauh mengapa hal tersebut dapat terjadi dan bagaimana cara mengatasinya

\section{Rumusan Masalah}

1. Bagaimana perilaku masyarakat di Kota Pontianak dalam menghadapi virus corona (Covid-19) ?

2. Apakah dampak dari virus corona (Covid-19) benar-benar dirasakan oleh masyarakat Kota Pontianak?

\section{Tujuan Penelitian}

1. Untuk menganalisis dan mengetahui perilaku masyarakat di Kota Pontianak dalam menghadapi virus corona (Covid-19).

2. Untuk menganalisis dan mengetahui dampak dari virus corona (Covid-19) terhadap masyarakat di Kota Pontianak.

\section{TINJAUAN TEORITIS}

Virus Corona (Covid-19) 
Coronavirus adalah kumpulan virus yang bisa menginfeksi sistem pernapasan.

Pada banyak kasus, virus ini hanya menyebabkan infeksi pernapasan ringan, seperti flu. Namun, virus ini juga bisa menyebabkan infeksi pernapasan berat, seperti infeksi paru-paru (pneumonia).Selain virus SARS-CoV-2 atau virus Corona, virus yang juga termasuk dalam kelompok ini adalah virus penyebab Severe Acute Respiratory Syndrome (SARS) dan virus penyebab Middle-East Respiratory Syndrome (MERS). Meski disebabkan oleh virus dari kelompok yang sama, yaitu coronavirus, COVID-19 memiliki beberapa perbedaan dengan SARS dan MERS, antara lain dalam hal kecepatan penyebaran dan keparahan gejala.

Perilaku Masyarakat

Perilaku adalah cara bertindak yang menunjukkan tingkah laku seseorang dan merupakan hasil kombinasi antara pengembangan anatomis, fisiologis dan psikologis (Kast dan Rosenweig, 1995). Terdapat tiga komponen yang mempengaruhi perilaku manusia, yaitu komponen kognitif, afektif, dan konatif.

1. Komponen kognitif merupakan aspek intelektual yang berkaitan dengan apa yang diketahui manusia.

2. Komponen afektif merupakan aspek emosional.

3. Komponen konatif adalah aspek volisional yang berhubungan dengan kebiasaan dan kemauan bertindak.

Unsur perilaku terdiri atas perilaku yang tidak nampak seperti pengetahuan (cognitive) dan sikap (affective), serta perilaku yang nampak seperti keterampilan (psychomotoric) dan tindakan nyata (action). Pola perilaku setiap orang bisa saja berbeda tetapi proses terjadinya adalah mendasar bagi semua individu, yakni dapat terjadi karena disebabkan, digerakkan dan ditunjukkan pada sasaran (Kast dan Rosenweig, 1995).

\section{METODE PENELITIAN}

Definisi Operasional Variabel

Variabel yang digunakan pada penelitian ini adalah perilaku masyarakat di Kota Pontianak. 
Bentuk Penelitian

Metode deskriptif digunakan untuk menggambarkan sifat suatu masalah yang sedang berlangsung pada saat penelitian dengan memeriksa sebab-sebab dari suatu gejala tertentu (Umar dalam Muliani, 2012). Tujuan dari penelitian deskriptif ini adalah untuk membuat deskriptif, gambaran, atau lukisan secara sistematik, faktual, dan akurat mengenai fakta-fakta, sifat-sifat, serta hubungan antar fenomena yang diselidiki.

Penelitian ini akan menggunakan data kualitatif sehingga analisis akan dilakukan secara kuantitatif dengan cara mengkuantifikasi data-data penelitian ke dalam bentuk angka-angka dengan menggunakan skala ratio (ratio scale) dan skala likert.

\section{Teknik Pengumpulan Data}

Pengumpulan data primer dalam penelitian ini dilakukan dengan kueisoner. Kueisoner adalah teknik pengumpulan data yang dilakukan dengan cara memberi seperangkat pertanyaaan atau pernyataan untuk dijawab oleh responden.

\section{Populasi dan Sampel}

Populasi dalam penelitian ini adalah masyarakat di Kota Pontianak. Jumlah populasi Kota Pontianak tahun 2019 menurut Dinas Kependudukan dan Pencatatan Sipil Kota Pontianak berjumlah 669.169 jiwa. Sampel adalah sebagian dari jumlah dan karakteristik yang dimiliki oleh populasi tersebut (Sugiyono, 2017). Penelitian ini menggunakan teknik probability sampling secara cluster sampling dimana sampel akan dibagi proporsional untuk masing-masing kecamatan di Kota Pontianak. Jumlah sampel yang akan digunakan menurut tabel Krejcie dan Morgan dengan populasi sebanyak 669 ribu maka sampel yang akan diambil adalah sebesar 382 sampel dan dianggap dapat mewakili populasi, dimana sampel ini akan dibagi merata di 6 kecamatan sehingga di masing-masing kecamatan akan didapat sampel sebanyak 63 sampel. 
HASIL DAN PEMBAHASAN

Responden terdiri dari $55 \%$ laki-laki dan $45 \%$ perempuan dengan $80 \%$ sudah bekerja dan $20 \%$ sedang tidak bekerja. Hasil data yang diperoleh menunjukkan bahwa $75 \%$ responden yang ada di Kota Pontianak menunjukkan sikap yang biasa saja terhadap pandemi virus corona (Covid-19) ini, responden masih merasa kurang peka terhadap ancaman virus corona (Covid-19) ini, hal ini dapat dilihat dari banyaknya masyarakat di Kota Pontianak ini yang sering keluar rumah walaupun tidak dalam keadaan yang penting atau darurat, selain itu masih banyaknya kepedulian masyarakat dalam menggunakan masker sesuai dengan anjuran pemerintah baik itu pusat maupun daerah, tentu saja ini sangat miris dan menjadi ancaman yang serius dari semakin meningkat dan menyebarnya virus corona (Covid19), padahal pemerintah Kota Pontianak sendiri sudah memberlakukan jam malam yang dimana setiap jam 19.00 malam banyak jalan-jalan pusat di Kota Pontianak yang ditutup dan dijaga oleh aparat yang bertugas, hal ini tentu saja untuk mencegah semakin banyaknya penularan dari virus corona (Covid-19), perilaku masyarakat Kota Pontianak tentu juga harus mendukung himbauan dari pemerintah dan mentaatinya sehingga baik pemerintah dan masyarakat Kota Pontianak dapat bersinergi dalam memberantas epidemi virus corona (Covid-19) terutama di Kalimantan Barat. Tentu ini tidak cukup saja dengan himbauan pemerintah perlu tindakan kolektif dan kerjasama dari semua lapisan asyarakat sehingga penyebaran virus corona (Covid-19) ini dapat ditekan.

Dampak dari virus corona (Covid-19) juga sangat dirasakan oleh masyarakat kota Pontianak, baik itu kalangan atas sampai ke bawah, hal ini dapat terlihat dari banyaknya restoran, rumah makan, café, warung kopi yang sudah tidak buka sejak 2 bulan yang lalu mentaati peraturan pemerintah, tentu saja ini berdampak bagi perekenomian baik itu pemilik maupun para karyawan. Selain itu industri UMKM (Usaha Mikro Kecil Menengah) tidak semua masyarakat memiliki status pekerjaan sebagai karyawan tetap. Sebagian bahkan kebanyakan dari mereka adalah pelaku usaha mikro kecil dan menengah, yang masuk dalam golongan atau kelompok masyarakat berpenghasilan tidak tetap dan harian. Penyebaran virus corona ini memberi pukulan keras bagi kelompok masyarakat ini, karena mereka 'terpaksa' 
harus menghentikan kegiatan usahanya. Artinya praktis pendapatan mereka

berkurang bahkan tidak memiliki penghasilan sama sekali Guncangan ekonomi mulai dirasakan ketika 'ketidakberdayaan' sebagai akibat dari pandemi virus corona ini dihantam dengan tekanan hidup. Di satu sisi mereka dituntut untuk bisa menghadapi situasi dan kondisi agar tetap survive, namun di sisi lain mereka pun dihadapkan pada beban tanggungan seperti biaya hidup sehari-hari, baik konsumsi maupun biaya-biaya lain termasuk cicilan kredit. Di saat mereka dalam posisi jobless tanpa penghasilan, mereka pun harus memenuhi kebutuhan untuk bisa melangsungkan kehidupannya. Jelas mereka tidak akan bisa survive dalam kondisi yang demikian. Perlu adanya campur tangan pemerintah yang memberikan subsidi yang setidaknya mampu menjamin kebutuhan dasar mereka. Dalam hal ini, pemerintah perlu bekerjasama dengan pihak terkait untuk memberikan kelonggaran segala macam pembayaran, seperti cicilan kredit, biaya listrik, dan lainnya.

\section{SIMPULAN DAN SARAN}

Berdasarkan hasil penelitian diatas dapat penulis simpulkan beberapa hal yaitu :

1. Perilaku masyarakat di Kota Pontianak tentu saja berpengaruh terhadap penyebaran virus corona (Covid-19) di Kota Pontianak, hal ini dapat dilihat dari semakin banyaknya jumlah pasien positif yang bertambah di Kota Pontianak dibandingkan dengan daerah-daerah lainnya yang ada di Kalimantan Barat.

2. Dampak yang ditimbulkan dari virus corona (Covid-19) sangat dirasakan oleh semua pihak, baik itu kalangan atas sampai dengan kalangan bawah, tentu saja ini harus menjadi perhatian bagi pemerintah dalam memperbaiki kondisi perekonomian yang ditimbulkan akibat virus corona (Covid-19).

Adapun saran yang diberikan oleh penulis adalah sebagai berikut :

1. Pemerintah di Kota Pontianak harus lebih tegas dalam pemberlakuan aturanaturan yang dimana dapat mengurangi bertambahnya pasien positif virus corona (Covid-19), harus ada sosialisasi secara terus menerus karena yang dibutuhkan adalah kerjasama kolektif antara masyarakat dengan pemerintah guna memutus mata rantai penyebaran virus corona (Covid-19), sekarang penyebaran sudah bukan dari luar lagi tetapi antara sesama masyarakat kota Pontianak, tentu saja ini 
lebih beresiko dan dapat menimbulkan semakin meningkatnya masyarakat yang

terjangkit virus corona (Covid-19) di Kota Pontianak. Pemberlakuan hidup bersih dan social distancing harus tetap ditaati oleh masyarakat di Kota Pontianak.

2. Pemerintah harus memberikan bantuan sosial kepada masyarakat yang terdampak dari virus corona (Covid-19) secara merata dan adil, sehingga kalangan menengah ke bawah khususnya dapat menikmati bantuan langsung tunai ini, dengan begitu tidak akan terjadi kesenjangan antara satu sama lain, hal ini juga diperlukan koordinasi yang baik antara tingkat pemerintah sampai ke tingkat lurah, rt/rw di Kota Pontianak ini.

\section{DAFTAR PUSTAKA}

Aida, N.R. 2020, Maret 19. Update Virus Corona di Dunia:214.894 Orang Terinfeksi, 83.313 Sembuh, 8.732 Meninggal Dunia. Kompas.com

Barak, Y. 2006. The immune system and happiness. Autoimmunity Reviews, 5 $8 ; 523-527$.

CNN Indonesia. 2020, Maret 14. Mengenai Social Distancing sebagai Cara Mencegah Corona. CNN Indonesia.

Kate anda Rosenwig. 1995. Behaviour, and thinking. New York:Farrar, Straus and Giroux.

Nisfiannoor, Muhammad. 2009. Pendekatan Statistika Modern, Jakarta : Badan Penerbit Salemba Huamanika.

www.tribunpontianak.com 